Boletín de la Sociedad Geológica Mexicana

VOLUMEN 66, NÚM. 3, 2014, P. 483-489

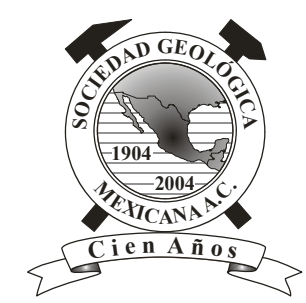

\title{
Cantabroxanthus loredoensis new genus, new species (Decapoda, Brachyura, Etyoidea) from the Middle Campanian of Loredo, Ribamontán al Mar, (Cantabria, northern Spain)
}

\author{
Àlex Ossó ${ }^{1, *}$, Manuel Díaz Isa ${ }^{2}$ \\ ${ }^{1}$ Josep Vicenç Foix, 12-H, 1er-1 a 43007 Tarragona, Catalonia. \\ ${ }^{2}$ Calle del Ingenio, 2, $2^{\circ}$ Dcha., 39012 Santander, Cantabria, Spain. \\ *aosso@comt.cat
}

\begin{abstract}
The discovery of Cantabroxanthus loredoensis n. gen., n. sp., from the Sponge Beds (middle Campanian) of Cantabria (Spain), increases the number of known Cretaceous brachyuran taxa that the coastline outcrops of Cantabria have yielded. The new genus is herein placed within the family Feldmanniidae (Etyoidea) on the basis of similarities with the genus Caloxanthus A. Milne-Edwards, 1864. Cantabroxanthus is also compared to the Palaeocorystoidea families, however important differences, for example, Cantabroxanthus possesses an entire supraorbital margin, preclude any relationship with Palaeocorystoidea.
\end{abstract}

Keywords: Cantabroxanthus, Decapoda, Etyoidea, Feldmanniidae, Campanian, Cantabria.

\section{Resumen}

El hallazgo de Cantabroxanthus loredoensis, nuevo género, nueva especie, en los niveles llamados Sponge Beds (Campaniano medio) de Cantabria (España), incrementa el número de nuevos taxones de decápodos braquiuros que el Cretácico de la Costa Cantábrica ha proporcionado. El nuevo género ha sido ubicado en la familia Feldmanniidae (Etyoidea) con base en sus similitudes con el género Caloxanthus A. Milne-Edwards, 1864. También se ha comparado Cantabroxanthus con las familias de Palaeocorystoidea, sin embargo, importantes diferencias como el margen supraorbital entero, descartan cualquier relación con esa superfamilia.

Palabras clave: Cantabroxanthus, Caloxanthus, Decapoda, Etyoidea, Feldmanniidae, Campanian, Cantabria. 


\section{Introduction}

Previous reports of decapod crustacean from the Cretaceous of Cantabrian Coast are mainly referred to the abundant and well-known mecochirid Meyeria magna M'Coy, 1849 from Upper Aptian-Lower Albian strata (López-Horgue, 2009; González-León et al., 2014). Scarce but interesting brachyuran taxa (Palaeocorystoidea) from the same levels have already been cited or described (Amézarri-Grandal et al., 1977; Van Bakel et al., 2012) or will be described in upcoming works (Ossó et al., in progress). In addition, some brachyurans have also been recognized from the Cretaceous of the same area including: Homolopsis sp. (Homolidae), Caloxanthus formosus A. Milne-Edwards, 1864 (Feldmanniidae) and two unidentified raninids from the Cenomanian; Cenomanocarcinus sp. (Cenomanocarcinidae) from the Turonian; Graptocarcinus urbasaensis Van Bakel, Guinot, Corral and Artal, 2012 from the Santonian, and a possible graptocarcininid (Dynomenidae) from the Maastrichtian.

Cantabroxanthus loredoensis n. gen., n. sp. increases the number of brachyurans from the Cretaceous of Cantabrian Coast and represents a new form within the Feldmanniidae (Etyoidea).

\section{Geological settings}

Upper Cretaceous exposures in Cantabria are mainly restricted to the Santander coastal areas that belong to the North Cantabrian Basin (Figure 1). They are well exposed in Santander and in the neighbouring villages of Langre and Loredo (East) and Arnia (West). Campanian outcrops, exposed as coastal cliffs, permit a good lateral correlation of the beds.

In Langre ( $3 \mathrm{~km}$ east of Loredo), coastal cliff exposures permit a complete study of the section from Santonian to Campanian time. Schlüter (2009) proposed five litho units, ranging from lower to middle Campanian for these exposures: Holaster similis Marls, Sponge Rhythmites, Burrow Infilled Generated Facies, Pycnodonte Layers and Globator Beds (Figure 2). This section is well correlated with the neighbouring Loredo outcrops. The crab described in this study was collected from the basal part of the Sponge Beds, middle Campanian (Menabites delawarensis zone) that overlies the lower Campanian Holaster similis Marls (Rehfeld and Otto, 1995) (Figure 3). The sponge Beds consist of alternating marl-limestone beds deposited on a distal shelf that grade into shallow marine ramp carbonates with tempestites, indicating deposition above storm wave base (Schlüter et al., 2004). The dominant fauna are sponges,

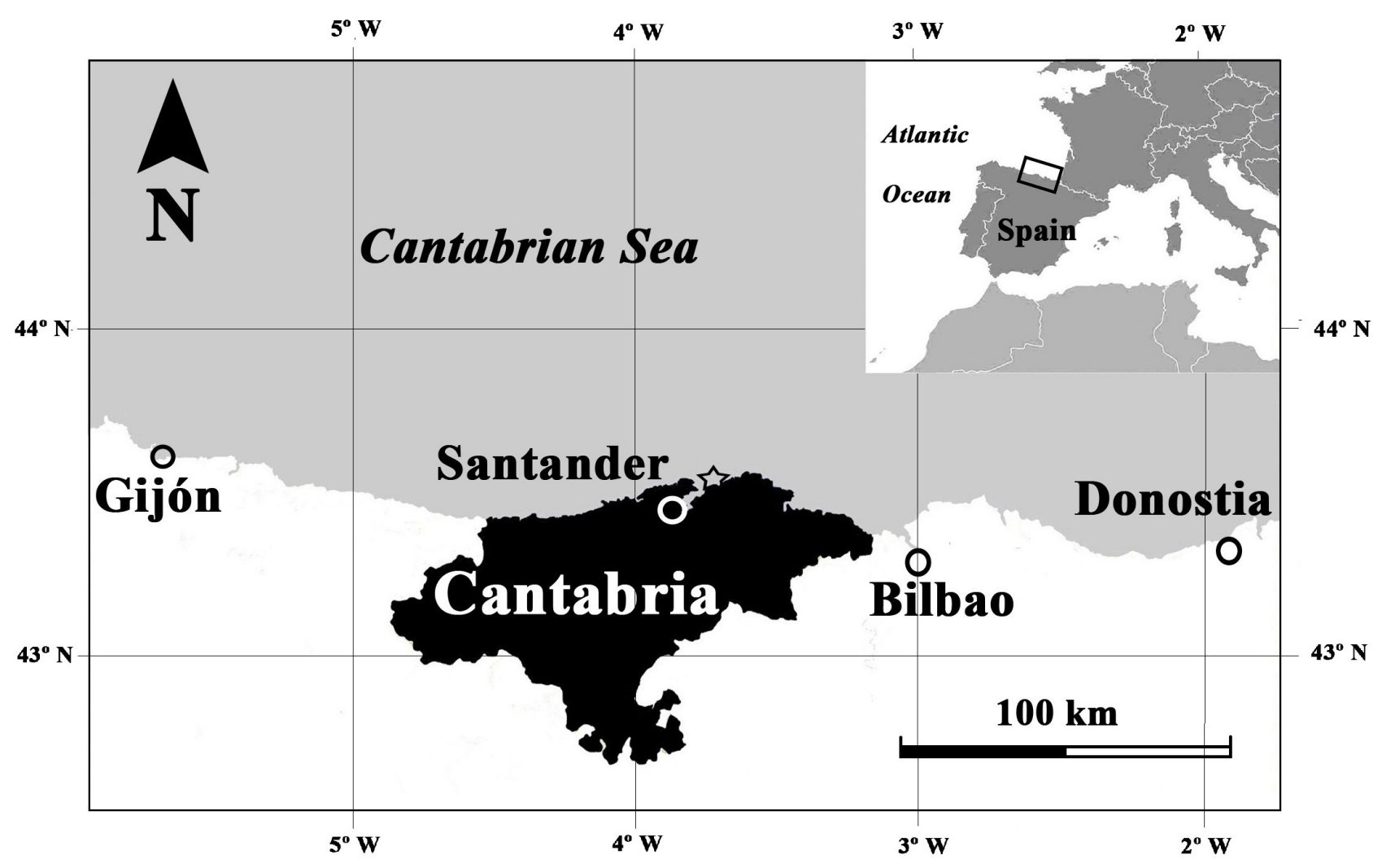

Figure 1. Location map of Cantabria region in northern Spain. Star indicates fossil locality. 


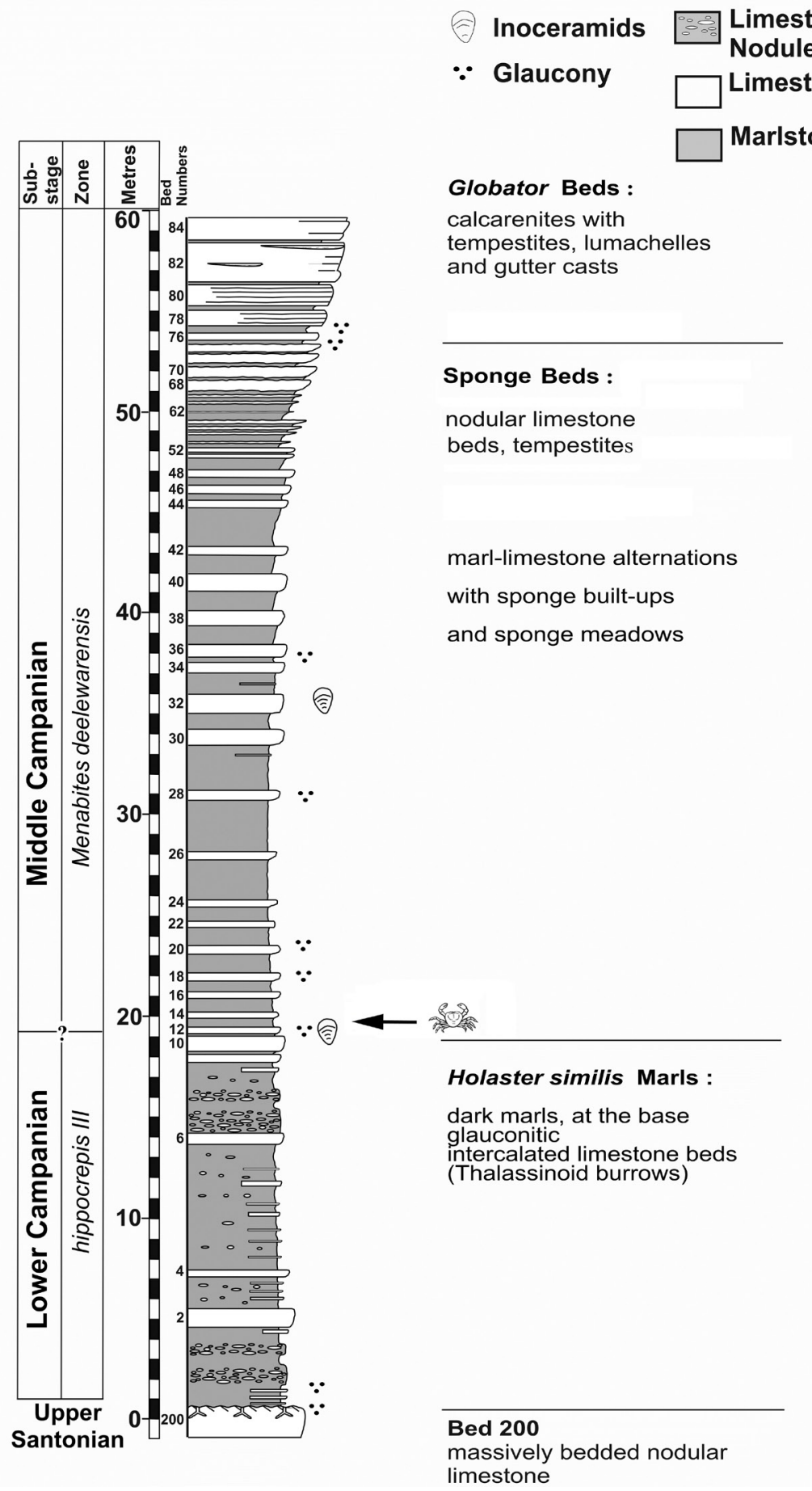

Figure 2. Stratigraphic column of Langre Section. Modified from Schlüter (2009).

Exogira spinosa, and echinoids (Schlüter et al., 2004). Additional information on the geology of the area can be found in Rehfeld and Otto (1995), Wilmsen et al. (1996), and Schlüter et al. (2004).

The specimen here described is housed in the Museo Marítimo del Cantábrico of Santander (Cantabria, Spain), acronym MMCAN.

\section{Systematic paleontology}

Infraorder Brachyura Latreille, 1802

Section Podotremata Guinot, 1977

Superfamily Etyoidea Guinot \& Tavares, 2001

Family Feldmanniidae Schweitzer, Feldmann, Franţescu \& Klompmaker, 2012 


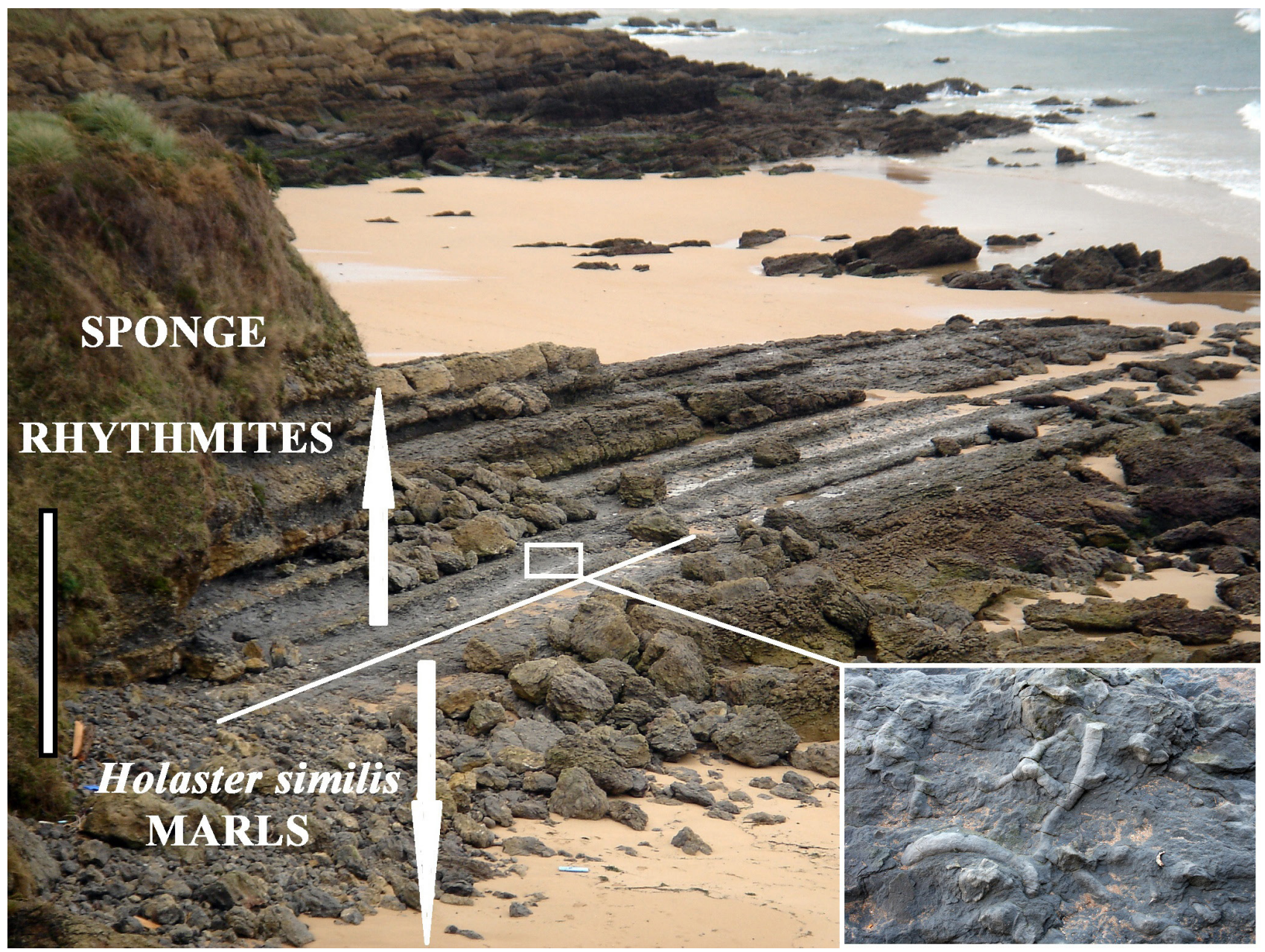

Figure 3. View of outcrops (Loredo's Beach) with close-up view of crab bearing level (rectangle). Scale bar $=1 \mathrm{~m}$.

\section{Genus Cantabroxanthus n. gen.}

Type species: Cantabroxanthus loredoensis n. sp.

Etymology: The genus name refers to the Cantabrian Coast, northern Iberian Peninsula, and the sufix -xanthus, for the similarities with Caloxanthus.

Type locality and horizon: The fossil crab described here was collected from talus beach rock in the village of Loredo, municipality of Ribamontán al Mar (Cantabria, Spain); middle Campanian.

Material and measurements (in mm): Holotype MMCAN/2014/0003: carapace length $15 \mathrm{~mm}$, carapace width $20 \mathrm{~mm}$, orbito frontal width $13 \mathrm{~mm}$, frontal width 6 $\mathrm{mm}$, posterior margin width $8 \mathrm{~mm}$.

Diagnosis: Carapace small, hexagonal, slightly ovate transversely, wider than long, widest at anterior third, convex in both directions, anterior third longitudinally deflexed; strong cuticle with coarse granules; frontal margin broken; orbits relatively broad, transversely ovate, entire, supraorbital margin rimmed, finely granulated; anterolateral margin strongly convex, bordered by six small spaced granulated lobes; posterolateral margin straight, bordered by granules; posterior margin straight, vaulted, rimmed by a parallel row of granules; carapace regions evident; hepatic region slightly swollen; lobes of protogastric region strongly inflated, mesogastric region narrow anteriorly, metagastric region narrow, urogastric region depressed, smooth; lobes of epi-mesobranchial region strongly inflated, metabranchial region depressed, smooth; lobe of cardiac region rhomboidal, axially elongate, inflated; intestinal region depressed, smooth; cervical groove anteriorly placed, deep, smooth.

Discussion: Cantabroxanthus $\mathrm{n}$. gen. is here in tentatively placed within Feldmanniidae (Etyoidea) that includes the genera: Bretonia Schweitzer, Feldmann, Franţescu and Klompmaker, 2012, Caloxanthus and Feldmannia Guinot and Tavares, 2001 (see Schweitzer et al., 2102) on the basis of some similarities with Caloxanthus.

Cantabroxanthus $\mathrm{n}$. gen. has some affinities with the genus Caloxanthus A. Milne-Edwards, 1864 (Feldmanniidae) in having a similar transversally ovate carapace ornamented with coarse granules, maximum width at the anterior third of carapace, large oval orbits that are forward directed, an 
entire supraorbital margin without fissures, an orbital rim strongly elevated and a cervical groove anteriorly placed. Cantabroxanthus differs from Caloxanthus in not having a transversally ovate carapace, having an anterolateral margin with lobes instead of the smooth ones as in Caloxanthus and also by having regions well-defined whereas in Caloxanthus they are poorly defined (Schweitzer et al., 2012; Vega et al., 2014). Bretonia differs from Cantabroxanthus n. gen. in having a smooth carapace without well marked regions and having a supraorbital margin with two fissures instead of the entire margin as in Cantabroxanthus (see Collins and Breton, 2009, p. 47-49, f. 8-9). Feldmannia differs from Cantabroxanthus in having a wider carapace, being ornamented with granules not as coarse and having lessdefined regions.

Furthermore, all genera belonging to the other Etyoidea: Etyidae Guinot and Tavares, 2001 differ from Cantabroxanthus n. gen. in having a wider carapace, a maximum width placed more posteriorly, and more strongly dentate anterolateral margins. In addition, the cervical groove in Etyidae is is more sinuous and placed more posteriorly than in Cantabroxanthus n. gen., and the epi-mesobranchial lobes are differentiated by two well-marked branchial grooves (bg1 and bg2 ), whereas in Cantabroxanthus n. gen. those two lobes are not differentiated (see Schweitzer et al., 2012).

The above mentioned affinities are important characters that Cantabroxanthus n. gen. shares with Caloxanthus, allowing tentative placement of Cantabroxanthus n. gen. within the Feldmanniidae. No ventral features preserved in the sole specimen of Cantabroxanthus n. gen. permit comparing it with the typically strongly deflexed sternum seen in the Feldmanniidae (see Schweitzer et al., 2012, Vega et al., 2014).

The general shape of Cantabroxanthus n. gen., is similar to several members of Palaeocorystoidea, Lörenthey in Lörenthey and Beurlen, 1929 as Paranecrocarcinus Van Straelen, 1936 (Paranecrocarcininae, Necrocarcinidae), with similarities like expanded anterolateral margins and carapace ornamented with coarse granules in some of their species such as Paranecrocarcinus quadriscissus (Noetling, 1881). Cantabroxanthus n. gen. differs from Paranecrocarcinus in having a larger and apparently straight front, broader frontal and fronto-orbital margin and mainly by having the supraorbital margin entire without fissures. In Paranecrocarcininae Fraaije, Van Bakel, Jagt \& Artal, 2008 the supraorbital margin has two fissures. Furthermore in Cantabroxanthus n. gen. the postfrontal slits are absent, which are a diagnostic character for the Paranecrocarcininae (Fraaije et al., 2008, p. 201; Van Bakel et al., 2012).

Other genera of Palaeocorystoidea show some resemblance to Cantabroxanthus n. gen., however there are evident differences. The new genus differs from Necrocarcinidae Förster, 1968, in lacking the usual strong dorsal tubercles, having a broader frontal and frontorbital margin and by its supraorbital margin being entire whereas in Necrocarcinidae the supraorbital margin is bi-fissured. Shazella Collins and Williams, 2004 (Necrocarcinidae) possesses a posterior carapace half with three axial inflations that is similar to Cantabroxanthus, however Shazella has a straight anterolateral margin that is not as laterally expanded as in Cantabroxanthus, ruling out any relationship between the two genera. Absence of well-developed epibranchial spines and of the diagnostic three axial ridges in Cantabroxanthus n. gen. precludes its placement in Cenomanocarcinidae Guinot, Vega and Van Bakel, 2008. Also, not having the spiny frontal margin as in Cantabroxanthus, excludes any relationship with the family Orithopsidae Schweitzer, Feldmann, Fam, Hessin, Hetrick, Nyborgand, Ross, 2003. Absence of the two supraorbital fissures present in all families of Palaeocorystoidea rules out placement of Cantabroxanthus within the Palaeocorystoidea (see Van Bakel et al., 2012).

\section{Cantabroxanthus loredoensis n. gen.}

Figure 4

Etymology: From Loredo, village of the municipality of Ribamontán al Mar, Cantabria (Spain), where the holotype was collected.

Diagnosis: as for the genus.

Description: Carapace sub-hexagonal, slightly ovate transversely, wider than long, widest at anterior third, at level of third anterolateral lobe, slightly convex transversally and longitudinally, strongly convex at anterior third; strong cuticle with coarse granules covering all the regions inflated; frontal margin broken, probably not prominent; orbits relatively broad, transversely ovate, supraorbital margin entire, rimmed, elevated, finely granulated and forward directed; anterolateral margin strongly convex, bordered by six small spaced granulated lobes; posterolateral margin straight, bordered by granules; posterior margin straight, vaulted in posterior view, rimmed by a parallel row of granules; carapace regions well marked; hepatic region slightly swollen; epigastric lobes inflated, lobes of protogastric region strongly inflated, anteriorly divided by a groove, mesogastric region anteriorly narrow, metagastric region narrow marked by a two transversal rows of granules, urogastric region narrow, depressed, smooth; lobes of epi-mesobranchial region strongly inflated, metabranchial region depressed, smooth, ornamented with few scattered granules; lobe of cardiac region rhomboidal, axially elongate, inflated, reaching almost the posterior margin; intestinal region depressed, very reduced, smooth; cervical groove deep, smooth, anteriorly placed.

\section{Conclusion}

The discovery of Cantabroxanthus loredoensis n. gen., n. sp. expands the knowledge of the Etyoidea showing a new pattern of carapace shape not previously seen for this 


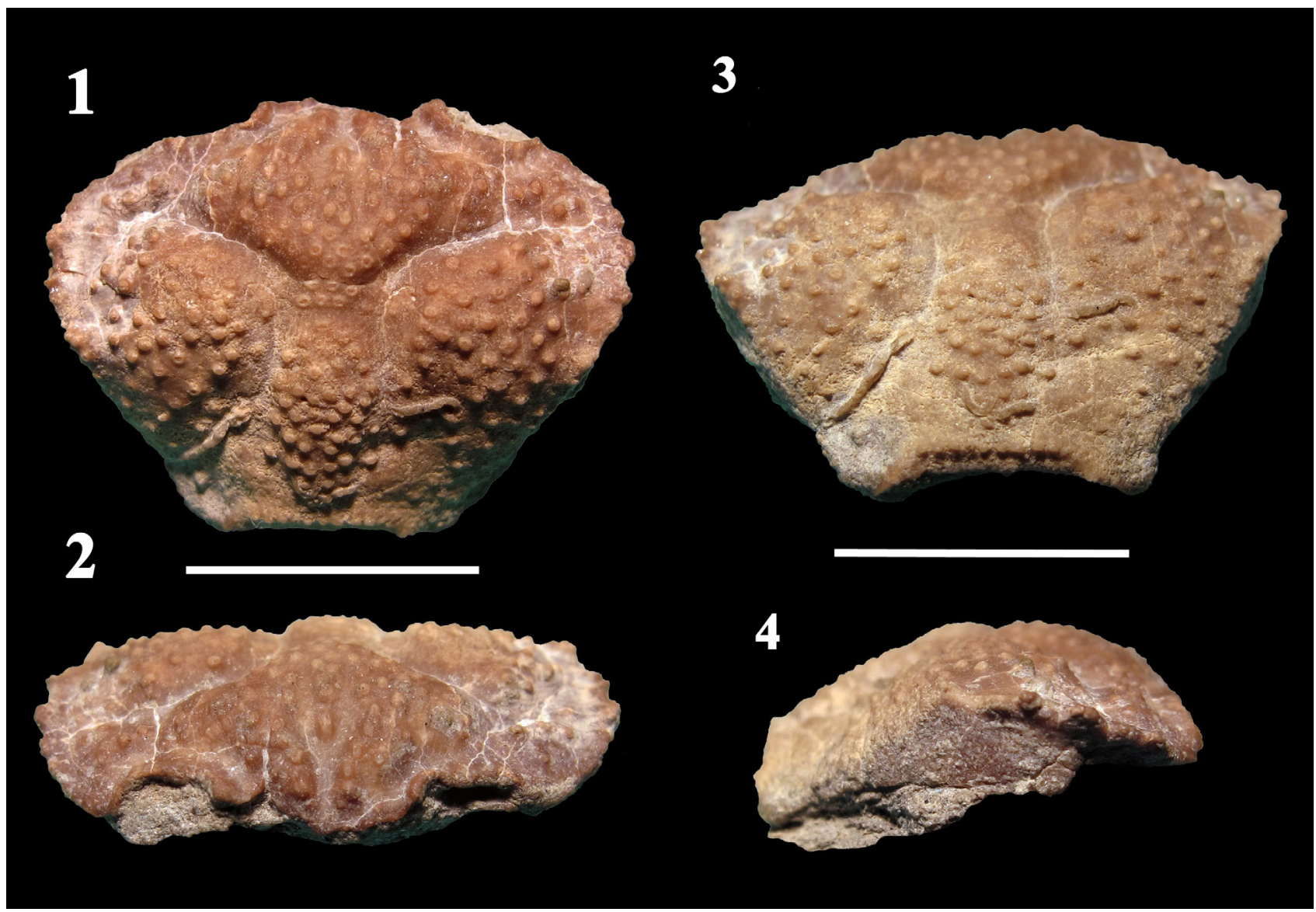

Figure 4. Cantabroxanthus loredoensis $\mathrm{n}$. gen. n. sp. Holotype MMCAN/2014/0003 1-dorsal view. 2-frontal view. 3-posterior view. 4-right lateral view. Scale bar $=1 \mathrm{~cm}$

superfamily. Works in progress on Etyoidea (Van Bakel) will improve the understanding of this group with new data.

\section{Acknowledgements}

We thank Torrey Nyborg (Department of Earth and Biological Sciences, Loma Linda University, Loma Linda, California, USA) and Barry Van Bakel (NCB Naturalis\& De Groene Poort Boxtel, the Netherlands) for their detailed review and suggestions that helped to improve this paper.

\section{References}

Amézarri-Grandal, E., Galán-Fernández, R., Saiz de Omeñaca, J., ViaBoada, L., (1977), Nota previa sobre un nuevo yacimiento de Braquiuros Cretácicos, en Ribamontán al Mar (Santander): Breviora Geologica Asturica, 4, 49-50.

Collins, J.S.H., Breton, G., 2009, New crabs (Crustacea, Decapoda) from the Cenomanianstratotype (Western Paris Basin, France): Bulletin of the Mizunami Fossil Museum, 35, 43-50.

Collins, J.S.H., Williams, R.J., 2004, A new genus and species of necrocarcinid crab (Crustacea, Brachyura) from the Upper Cretaceous of England: Bulletin of the Mizunami Fossil Museum, 31, 33-35.
Förster, R., 1968, Paranecrocarcinus libanoticus [sic] n. sp. und die Entwicklungder Calappidae in derKreide: Mitteilungenaus der Bayerischen Staatssammlung für Paläontologie und historische Geologie, 8, 167-195.

Fraaije, R.H.B., Van Bakel, B.W.M., Jagt, J.W.M., Artal, P., 2008, New decapod crustaceans (Anomura, Brachyura) from mid-Cretaceous reefal deposits at Monte Orobe (Navarra, northern Spain), and comments on related type-Maastrichtian material, in Steurbaut, E., Jagt, J.W.M., Jagt-Yazykova, E.A. (Eds.), Annie V. Dhondt Memorial Volume: Bulletin de l'Institut royal des Sciences naturelles de Belgique, Sciences de la Terre, 78, 193-208.

González-León, O., Moreno-Bedmar, J.A., Vega, F. J., 2014, Morphology and ontogeny of Meyeria magna M'Coy, 1849 (Astacidae, Mecochiridae) from the Lower Cretaceous (lower Aptian) of Mexico, United Kingdom and Spain: Neues Jahrbuch für Geologie und Paläonlologie, Abhandlungen, 271, 1, 49-68.

Guinot, D., 1977, Propositions pour une nouvelle classification des Crustacés Décapodes Brachyoures: Comptes Rendus des Séances hebdomadaires de l'Académie des Sciences (Paris), D285, 10491052.

Guinot, D., Tavares, M., 2001, Une nouvelle famille de crabes du Crétacé, et la notion de Podotremata Guinot, 1977 (Crustacea, Decapoda, Brachyura): Zoosystema, 23, 507-546.

Guinot, D., Vega, F.J., Van Bakel, B.W.M., 2008, Cenomanocarcinidae n. fam., a new Cretaceous podotreme family (Crustacea, Decapoda, Brachyura, Raninoidia), with comments on related families: Geodiversitas, 30(4), 681-719.

Latreille, P.A., 1802-1803, Histoire naturelle, généraleet particulière des crustacés et des insectes, 3: 468 pp., Paris (Dufart). 
López-Horgue, M.A., 2009, New occurrences of Meyeria magna M`Coy, 1849 (Decapoda, Mecochiridae) in the early Aptian and early Albian of the Basque Cantabrian Basin (North Spain): Geogaceta, 47, 25-28.

Lörenthey, E., Beurlen, K., 1929, Die fossilen Decapoden der Länder der Ungarischen Krone: Geologica Hungarica, (Palaeontologica), 3, $1-421,12$ tables, 16 pls.

M'Coy, F., 1849, On the classification of some British fossil Crustacea with notices of new forms in the University Collection at Cambridge: Annals and Magazine of Natural History, series 2, 4, 161-179.

Milne-Edwards, A., 1864, Monographie des Crustacés de la famille Cancériens: Annales des Sciences Naturelles, (Zoologie) (5) 1 (1864), 31-88.

Noetling, F., 1881, Uebereinige Brachyurenaus dem Senonvon Mastricht [sic] unddemTertiär Norddeutschlands: Zeitschrift der Deutschen Geologischen Gesellschaft, 33, 357-371.

Rehfeld, U., Otto, A., 1995, Distribution and preservation of siliceous sponges of the rhythmically bedded spongiolitic rocks in the Lower Campanian of northern Spain (Cantabria, Santander area): Response to autecology and sea level development: Berliner GeowissenschaftlicheAbhandlungen (E: Paläobiologie), 16, 109-127.

Schlüter, N., 2009, Palökologie irregülarer Echiniden-Vergesell schaftungen des Santon und Campan (Oberkreide) im NordKantabrischen Becken (Spanien): Berlin, Freie Universität Berlin, $\mathrm{PhD}$ dissertation, Doktorarbeit, $82 \mathrm{p}$.

Schlüter, N., Diaz-Isa, M., Wiese, F., 2004, Response of irregular echinoid assemblages to environmental changes: a case study from the (Lower/Middle Campanian of Cantabria (northern Spain) - preliminary data.): Drittes Treffen deutschsprachiger Echinodermologen, 29, 49-57.
Schweitzer, C.E., Feldmann, R.M., Fam, J., Hessin, W.A., Hetrick, S.W., Nyborg, T.G., Ross, R.L.M., 2003, Cretaceous and Eocene Decapod Crustaceans from Southern Vancouver Island, British Columbia, Canada: Ottawa, Canada, National Research Council Press, 66 p.

Schweitzer, C.E., Feldmann, R.M., Franţescu, O.M., Klompmaker, A., 2012, Revision of Etyidae Guinot and Tavares, 2001 (Crustacea, Brachyura): Journal of Paleontology, 86(1), 129-155.

Van Bakel, B.W.M., Guinot, D., Artal, P., Fraaije, R.H.B., Jagt, J.W.M., 2012, A revision of the Palaeocorystoidea and the phylogeny of raninoidian crabs (Crustacea, Decapoda, Brachyura,Podotremata): Zootaxa, 3215, $216 \mathrm{p}$.

Van Straelen, V., 1936, Crustacés Décapodes nouveaux ou peu connus de l'époque Crétacique: Bulletin du Musée Royal d'Histoire Naturelle de Belgique, 12 (45), 1-49.

Vega, F., Jackson, J., Ossó, À., 2014, Exceptional preservation of a late Cenomanian (Cretaceous) crab from Texas, USA: Boletín de la Sociedad Geológica Mexicana, 66, 1.

Wilmsen, M., Wiese, F., Ernst, G. 1996, Facies development, events and sedimentary sequences in the Albian to Maastrichtian of the Santander depositional Area, North Spain: Mitteilungenauddem Geologisch Paläontologischen Institutder Universität Hamburg, 77, 337-367.

Manuscript received: March 10, 2014.

Corrected manuscript received: April 20, 2014.

Manuscript accepted: April 24, 2014. 